\title{
DODATKOWE UBEZPIECZENIA ZDROWOTNE JAKO INSTRUMENT MOGĄCY USPRAWNIĆ FUNKCJONOWANIE SYSTEMU OCHRONY ZDROWIA W POLSCE
}

Streszczenie. W artykule poruszono tematykę zwiększającego się popytu na świadczenia w ramach systemu opieki zdrowotnej w Polsce. Zaprezentowane zostały czynniki determinujące ten wzrost. Omówiono zasady funkcjonowania systemu ochrony zdrowia. Wskazano dodatkowe ubezpieczenia zdrowotne jako instrument pozwalający na odciążenie państwowego systemu. Źródłem informacji ilościowych wykorzystywanych w pracy były opracowania GUS-u i Eurostatu.

Słowa kluczowe: system ochrony zdrowia, dobrowolne ubezpieczenia zdrowotne, długość życia, wydatki na ochronę zdrowia.

\section{WPROWADZENIE}

Konstytucja Rzeczypospolitej Polskiej gwarantuje obywatelom prawo do ochrony ich zdrowia. Niestety obecne uwarunkowania ekonomiczne i prawne nie pozwalają im w pełni korzystać z tego prawa. Wynika to przede wszystkim $z$ niedofinansowania państwowego systemu ochrony zdrowia, a także barier przy korzystaniu z procedur medycznych w ramach finansowania własnego. Komisja Europejska zarzuciła polskiemu systemowi nierówności w dostępie do świadczeń opieki zdrowotnej spowodowane długim czasem oczekiwania pacjentów na realizację usług medycznych (Fal 2013: 47). Prognozy Eurostatu wskazują, że społeczeństwo polskie starzeje się, a to w połączeniu $\mathrm{z}$ rozwojem medycyny zapewne powodować będzie zwiększone zapotrzebowanie na coraz droższe świadczenia zdrowotne. Aby system ochrony zdrowia działał efektywniej, należy rozważyć upowszechnienie współfinansowania świadczeń ze środków prywatnych za pośrednictwem instrumentu, jakim są dodatkowe ubezpieczenia zdrowotne.

Celem tego opracowania jest przedstawienie sytuacji polskiego systemu opieki zdrowotnej w obliczu zwiększającego się popytu na świadczenia medyczne. Jako instrument odciążający system publiczny wskazano dodatkowe ubezpieczenia zdrowotne.

\footnotetext{
*Uniwersytet Łódzki, Wydział Ekonomiczno-Socjologiczny, Katedra Ubezpieczeń.
} 


\section{ZASADY FUNKCJONOWANIA SYSTEMU OCHRONY ZDROWIA W POLSCE}

Art. 68 Konstytucji Rzeczpospolitej Polskiej gwarantuje wszystkim obywatelom prawo do równego dostępu, niezależnie od ich sytuacji materialnej, do świadczeń opieki zdrowotnej finansowanych ze środków publicznych. Ponadto zobowiązuje władze publiczne do zapewnienia szczególnej opieki zdrowotnej dzieciom, kobietom ciężarnym, osobom niepełnosprawnym i osobom w podeszłym wieku.

Ramy prawne funkcjonowania systemu ochrony zdrowia w Polsce oparte są na kilku podstawowych regulacjach. Wśród nich, oprócz Konstytucji Rzeczpospolitej Polskiej z dnia 2 kwietnia 1997 r., wyróżnić należy ustawę z dnia 27 sierpnia 2004 r. o świadczeniach opieki zdrowotnej finansowanych ze środków publicznych, ustawę z dnia 15 kwietnia 2011 r. o działalności leczniczej oraz rozporządzenia Ministra Zdrowia definiujące koszyki świadczeń gwarantowanych. Początkowo ustawa o świadczeniach opieki zdrowotnej finansowanych ze środków publicznych definiowała tzw. negatywny koszyk świadczeń. Dopiero nowelizacja z 2009 r. wprowadziła obowiązek wskazywania explicite świadczeń finansowanych ze środków publicznych. Rozporządzenia Ministra Zdrowia określają zakres świadczeń gwarantowanych w ramach: podstawowej opieki zdrowotnej, ambulatoryjnej opieki specjalistycznej, leczenia szpitalnego, rehabilitacji leczniczej, opieki psychiatrycznej i leczenia uzależnień, świadczeń pielęgnacyjnych i opiekuńczych w ramach opieki długoterminowej, leczenia stomatologicznego, leczenia uzdrowiskowego, zaopatrzenia w wyroby medyczne, ratownictwa medycznego, opieki paliatywnej i hospicyjnej, świadczeń wysokospecjalistycznych i programów zdrowotnych.

Podmiotami biorącymi udział w procesie zarządzania, nadzorowania i kontrolowania państwowym systemem opieki zdrowotnej są Ministerstwo Zdrowia (MZ), Ministerstwo Finansów (MF), Narodowy Fundusz Zdrowia (NFZ) oraz samorządy terytorialne. Ministerstwo Zdrowia wytycza kierunki prowadzonej polityki zdrowotnej. Do jego zadań należy również finansowanie i wdrażanie programów zdrowotnych, finansowanie wybranych świadczeń wysokospecjalistycznych, badania naukowe i kształcenie kadr medycznych. NFZ jest odpowiedzialny za proces kontraktowania oraz finansowania świadczeń medycznych u publicznych i niepublicznych świadczeniodawców. Do jego zadań należy również pokrywanie kosztów świadczeń udzielonych poza granicami kraju. Nadzór nad działalnością NFZ sprawuje MZ, a nadzór w zakresie gospodarki finansowej - MF. Za identyfikowanie potrzeb zdrowotnych swoich mieszkańców, planowanie podaży świadczeń zdrowotnych i promocję zdrowia odpowiedzialne są władze samorządowe (Golinowska 2012: 43).

Powszechny system ubezpieczeń zdrowotnych jest obowiązkowy dla obywateli Polski, a NFZ jest wyłącznym ubezpieczycielem w tym systemie. Obejmuje około 98\% populacji, w tym członków rodzin osób płacących składki ubezpieczeniowe oraz grupy społeczne, których składki pokrywane są z budżetu państwa 
(Golinowska 2012: 43). Osoby niepodlegające obowiązkowemu ubezpieczeniu mogą dobrowolnie do niego przystąpić. Obecnie obowiązujące rozwiązanie prawne nie daje pacjentom możliwości wyboru zakresu świadczeń ani sposobności współpłacenia za procedury medyczne.

Należy zauważyć, że oprócz świadczeń oferowanych w ramach państwowego systemu opieki zdrowotnej Polacy korzystają z usług medycznych pokrywanych ze środków prywatnych. Podkreślić trzeba jednak, że tylko mniej niż 10\% wydatków własnych stanowią składki na dodatkowe ubezpieczenia zdrowotne i abonamenty medyczne.

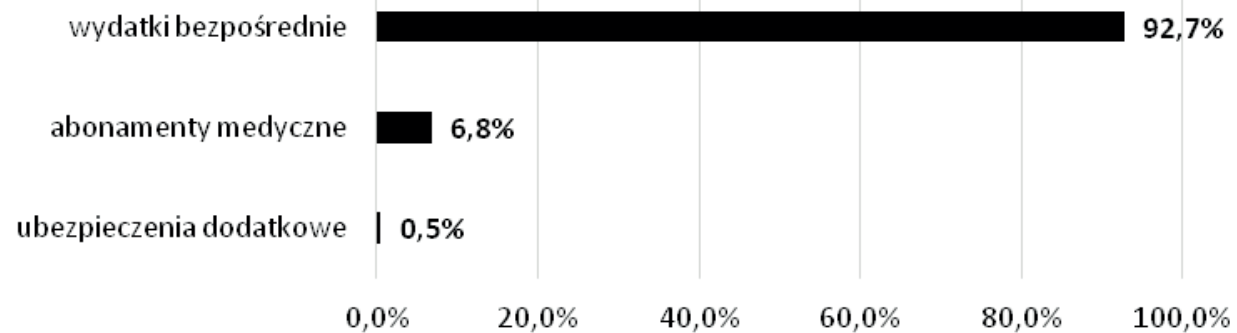

Wykres 1. Struktura wydatków własnych świadczeniobiorców na ochronę zdrowia - rok 2010

Źródło: PIU (2011: 12).

Zdecydowaną większość nakładów ogółem na ochronę zdrowia stanowią wydatki bieżące. Ich struktura kształtuje się następująco: NFZ, instytucje rządowe i samorządowe - poziom $70 \%$, a sektor prywatny - 30\%. Poniższe wykresy przedstawiają podział wydatków na ochronę zdrowia odpowiednio według grup wydatków (2a) i grup płatników (2b).

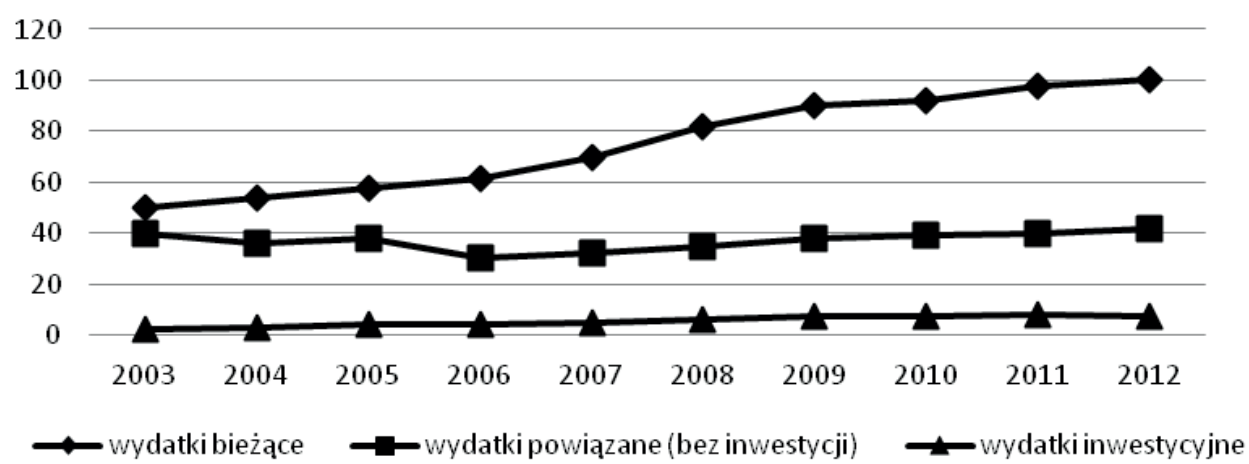

Wykres 2a. Wydatki na ochronę zdrowia w latach 2003-2012 (w mld zł) według grup wydatków Źródło: Koziński (2014: 6). 


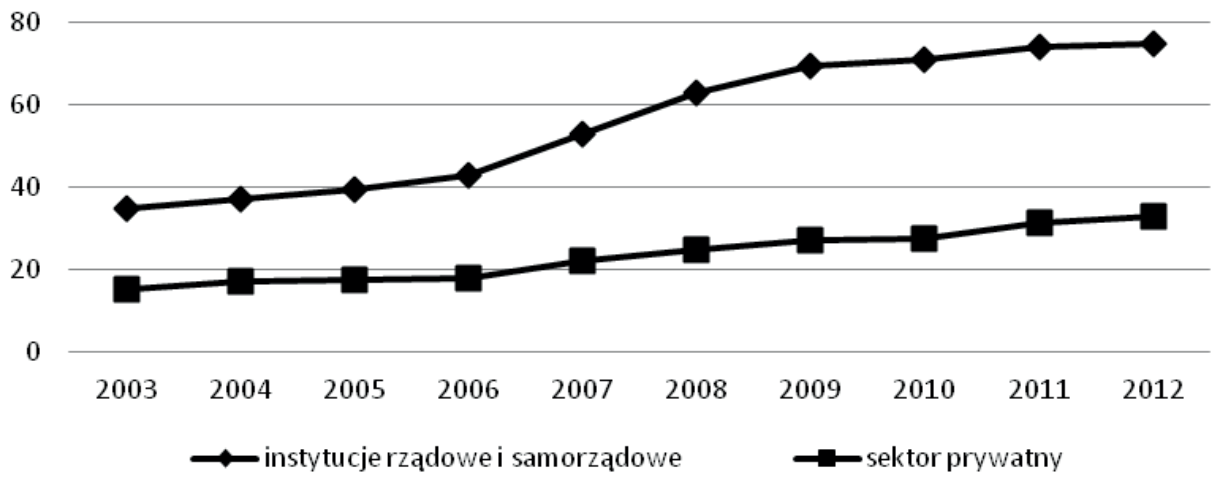

Wykres 2b. Wydatki na ochronę zdrowia w latach 2003-2012 (w mld zł) według grup płatników Źródło: Koziński (2014: 6).

\section{ROSNĄCE ZAPOTRZEBOWANIE NA ŚWIADCZENIA ZDROWOTNE}

Wyróżnić można trzy podstawowe czynniki, które wywołują zwiększony popyt na świadczenia zdrowotne (Rozkrut 2013: 33-34). Pierwszy z nich to czynnik demograficzny związany z postępującym starzeniem się społeczeństwa. Jak pokazują prognozy Eurostatu, społeczeństwo Unii Europejskiej (UE) będzie się starzeć. Jak widać na wykresie 3, proces starzenia się populacji Polski przebiegać będzie jednak dużo szybciej. W 2013 r. Polska zaliczała się do państw o najniższym udziale liczby osób w wieku 65+ do liczby osób w wieku produkcyjnym (1964 lat). Już w 2050 r. wskaźnik ten dla Polski przewyższy średnią dla całej UE.

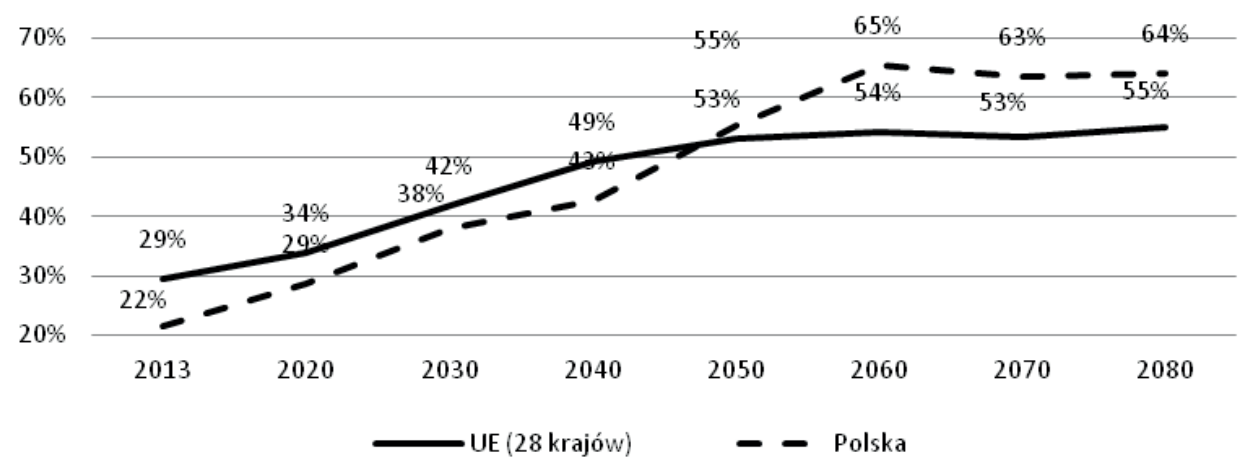

Wykres 3. Zmiana procentowego udziału liczby osób w wieku poprodukcyjnym (65+) w łącznej liczbie osób w wieku 19-64 w latach 2013-2080 - Polska vs. kraje Unii Europejskiej

Źródło: opracowanie własne na podstawie danych Eurostatu, http://epp.eurostat.ec.europa.eu/ portal/page/ portal/statistics/search_database (dostęp: 30.07.2014). 
Na wykresie 4 zobaczyć można procentowy udział populacji w wieku poprodukcyjnym w liczbie mieszkańców w wieku produkcyjnym w poszczególnych krajach członkowskich i państwach będących stroną układów i porozumień z UE.

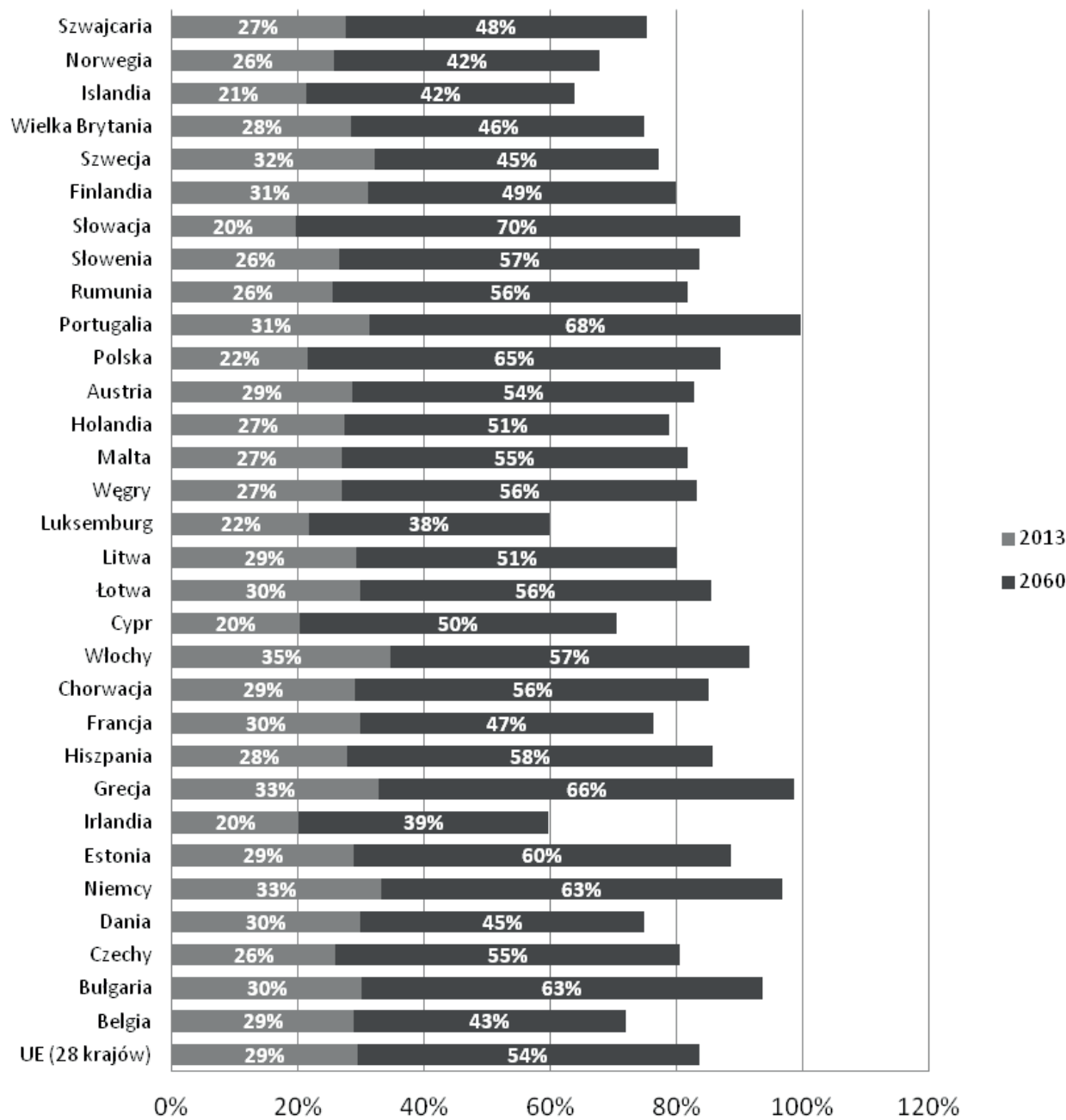

Wykres 4. Procentowy udział liczby osób w wieku poprodukcyjnym $(65+)$ w łącznej liczbie osób w wieku produkcyjnym (19-64 lata) - kraje Unii Europejskiej

Źródło: opracowanie własne na podstawie danych Eurostatu, http://epp.eurostat.ec.europa.eu/ portal/page/portal/statistics/search_database (dostęp: 30.07.2014).

Wykres 5 przedstawia zmiany struktury wiekowej w populacji Polski. Jak można zauważyć, liczba osób w wieku 60+ wzrośnie z 6,37 mln dla roku 2010 (16,64\% ludności Polski) do 12,94 mln w roku 2060 (37,14\% ogółu mieszkańców). 
Jednocześnie zmniejszeniu ulegnie odsetek osób w wieku 20-59 lat - z 54,83\% łącznej liczby ludności dla roku 2010 do 45,28\% w roku 2060.

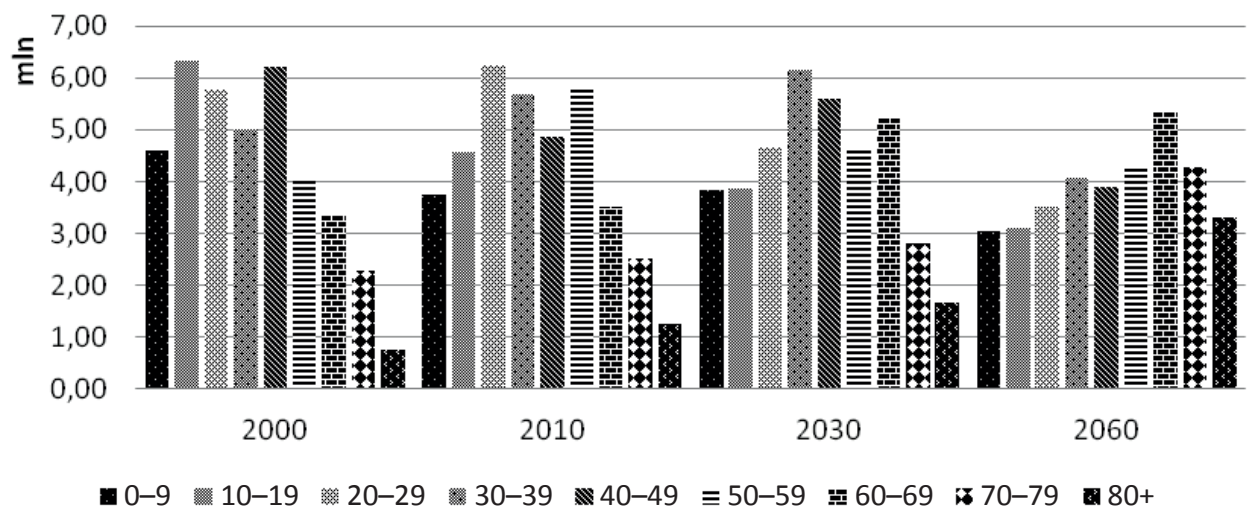

Wykres 5. Zmiany rozkładu wiekowego w populacji Polski - lata 2000, 2010, 2030, 2060

Źródło: opracowanie własne na podstawie danych Eurostatu, http://epp.eurostat.ec.europa.eu/ portal/page/portal/statistics/search_database (dostęp: 30.07.2014).

Średnie wydatki NFZ na jednego obywatela różnią się znacząco w zależności od grupy wiekowej, do której przynależy. Dla grupy 65+ średnia jest niemal trzy razy wyższa od tej dla młodszej części populacji. W obliczu zmiany struktury wiekowej mieszkańców zaskutkuje to niewątpliwie zwiększeniem popytu na świadczenia medyczne i koniecznością zwiększenia poziomu finansowania.

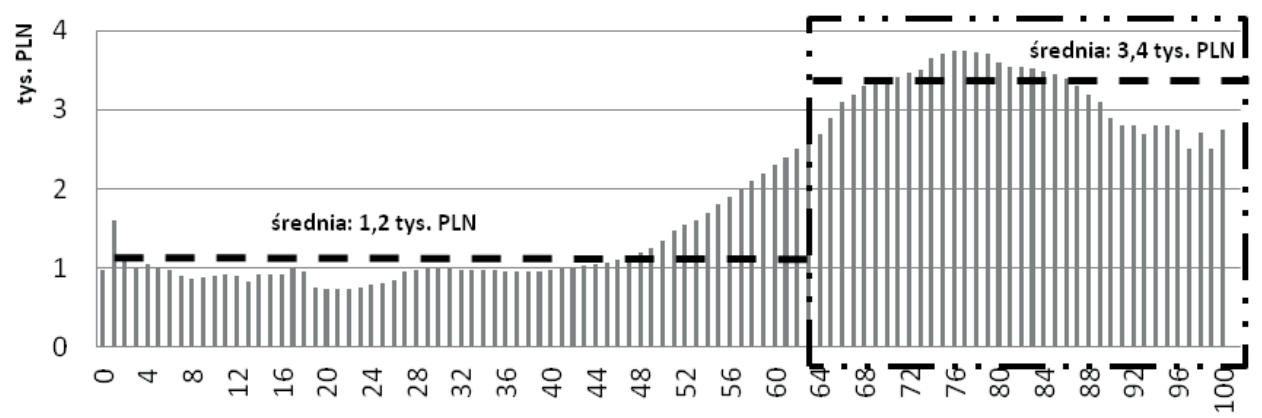

Wykres 6. Profil wydatków NFZ na świadczenia opieki zdrowotnej w Polsce na mieszkańca w zależności od wieku - rok 2011

Źródło: Rozkrut (2013: 39).

Drugim bardzo istotnym czynnikiem determinującym wzrost popytu na świadczenia medyczne jest element wzrostu zamożności społeczeństw. Wydatki 
na ochronę zdrowia są silnie związane z poziomem rozwoju gospodarczego, przy czym elastyczność dochodowa tych wydatków jest wyższa niż 1 (Rozkrut 2013: 34). Wykres 6 pokazuje rosnący poziom dochodu pozostającego w dyspozycji gospodarstw domowych. Jednocześnie procentowy udział wydatków do przeciętnej wartości dochodów w ostatnich latach ma tendencję malejącą.

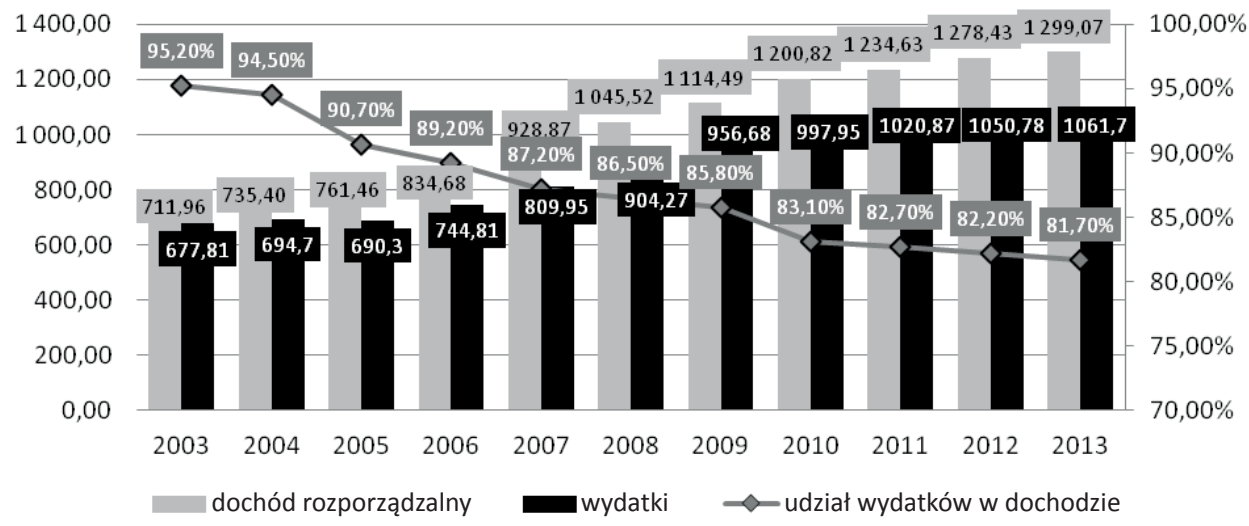

Wykres 7. Poziom przeciętnych miesięcznych dochodów i wydatków na osobę w gospodarstwie domowym oraz udział wydatków w dochodzie rozporządzanym - lata 2003-2013

Źródło: Siwiak (2014: 1).

Na wykresie 8 zaprezentowano zmianę wydatków na ochronę zdrowia w relacji do PKB w ostatnich latach w Polsce. Udział ten wzrósł z 5,98\% w roku 2003 do $6,33 \%$ w 2012.

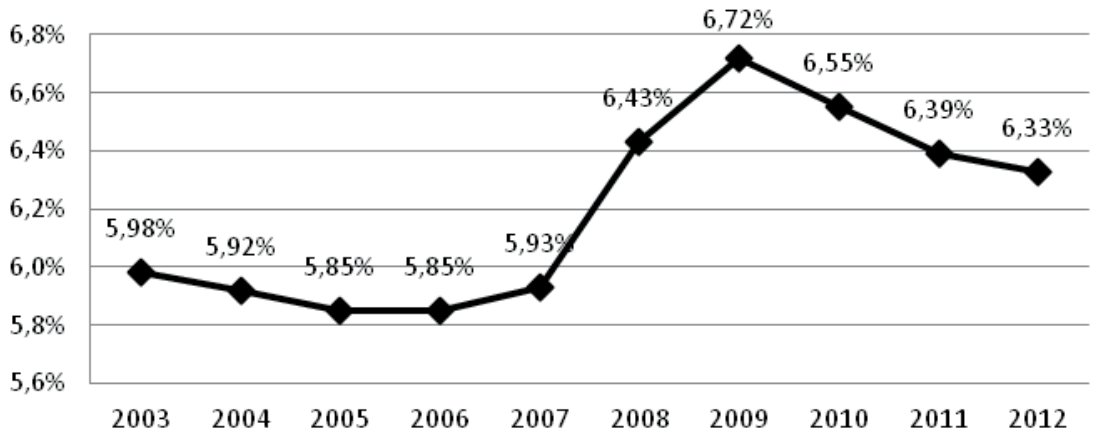

Wykres 8. Wydatki na ochronę zdrowia (bez inwestycji) w relacji do PKD w Polsce w latach 2003-2012

Źródło: opracowanie własne na podstawie danych Eurostatu, http://epp.eurostat.ec.europa.eu/ portal/page/portal/statistics/search_database (dostęp: 30.07.2014). 
Udział wydatków na ochronę zdrowia w PKB w latach 2003-2007 utrzymywał się na stabilnym poziomie 5,9\%, przez następne dwa lata obserwować można było wzrost do poziomu $6,72 \%$ dla roku 2009. Od roku 2010 tempo wzrostu wydatków na zdrowie było niższe niż wzrost PKB. W roku 2012 wydatki na ochronę zdrowia do PKB osiągnęły poziom $6,33 \%$.

Ostatnim czynnikiem powodującym zwiększenie wydatków w obszarze ochrony zdrowia jest rozwój technologii i wiedzy medycznej. Rozwój nowych technologii umożliwia rozszerzenie listy chorób podlegających leczeniu, a to rodzi większy popyt na nowe, często bardzo kosztowne, procedury medyczne.

\section{DODATKOWE UBEZPIECZENIA ZDROWOTNE}

Działający w Polsce system publicznego ubezpieczenia zdrowotnego, pomimo wzrostu nakładów finansowych na zabezpieczenie świadczeń zdrowotnych, wciąż nie jest wystarczająco efektywny i boryka się z wieloma problemami dotykającymi bezpośrednio świadczeniobiorców. Pomimo podwojenia poziomu nakładów na opiekę medyczną w ostatniej dekadzie Polacy nie oceniają systemu ochrony zdrowia jako skutecznie zaspokającego ich potrzeby.

Podstawową dysfunkcją polskiego powszechnego systemu ochrony zdrowia jest dysproporcja pomiędzy zawartością koszyków gwarantowanych świadczeń a wielkością środków na ich finansowanie. Taki stan rzeczy skutkuje trudnościami w dostępie i reglamentacją świadczeń zdrowotnych. Ustalane limity w ramach kontraktowania świadczeń z NFZ prowadzą do permanentnego zadłużania się świadczeniodawców (Łanda 2013: 15).

Dalszy wzrost wydatków publicznych na ochronę zdrowia albo pogorszyłby saldo sektora finansów publicznych, albo spowodowałby podniesienie składek na obowiązkowe ubezpieczenia zdrowotne, albo wymusił ograniczenie innych wydatków finansowanych z budżetu państwa. Zatem w obliczu rosnącego popytu na świadczenia zdrowotne konieczne stanie się wprowadzenie alternatywnego źródła finansowania. Mało prawdopodobna bowiem wydaje się, w perspektywie kilku najbliższych lat, realizacja scenariusza istotnego wzrostu wydatków publicznych na ochronę zdrowia (PIU, E\&Y 2013: 10). Wprowadzenie współfinansowania świadczeń zdrowotnych ze środków prywatnych za pośrednictwem uregulowanego prawnie instrumentu - dodatkowych ubezpieczeń - mogłoby zmniejszyć obciążenie publicznego systemu ochrony zdrowia.

Przez dodatkowe ubezpieczenie zdrowotne, zgodnie z definicją zaproponowaną przez Polską Izbę Ubezpieczeń (PIU), rozumieć będziemy „ubezpieczenie obejmujące finansowanie lub zapewnienie przez zakład ubezpieczeń świadczeń 
opieki zdrowotnej na rzecz ubezpieczonego związanych z profilaktyką lub terapią następstw wypadku lub choroby" (PIU, E\&Y 2013: 14).

Dodatkowe ubezpieczenia zdrowotne mogą funkcjonować jako alternatywne, uzupełniające lub równoległe w stosunku do bazowego systemu ochrony zdrowia. Występować mogą również systemy mieszane. Rola, jaką dodatkowe ubezpieczenia odgrywają w systemie opieki zdrowotnej, zależy przede wszystkim od formy i zakresu funkcjonującego bazowego systemu zabezpieczenia zdrowotnego. W tab. 1 przedstawiono krótkie charakterystyki trzech wskazanych form umiejscowienia ubezpieczeń dodatkowych w systemie ochrony zdrowia.

Tabela 1

Prywatne ubezpieczenia zdrowotne w relacji do funkcjonującego system bazowego

\begin{tabular}{|c|c|c|}
\hline $\begin{array}{c}\text { Rodzaj } \\
\text { ubezpieczenia }\end{array}$ & $\begin{array}{c}\text { Relacja w stosunku } \\
\text { do systemu bazowego }\end{array}$ & \multicolumn{1}{c|}{ Charakterystyka } \\
\hline $\begin{array}{c}\text { komplementarne } \\
\text { (uzupełniające) }\end{array}$ & „ponad” & $\begin{array}{l}\text { - dostęp do świadczeń nieobjętych systemem } \\
\text { bazowym } \\
- \text { ubezpieczenie od współpłacenia }\end{array}$ \\
\hline $\begin{array}{c}\text { suplementarne } \\
\text { (równoległe) }\end{array}$ & „obok” & $\begin{array}{l}\text { - szybszy dostęp do świadczeń } \\
\text { - szerszy wybór świadczeniodawców } \\
\text { - wyższa jakość świadczenia }\end{array}$ \\
\hline $\begin{array}{c}\text { substytucyjne } \\
\text { (alternatywne) }\end{array}$ & „zamiast” & $\begin{array}{l}\text { - dla osób wyłączonych z systemu bazowego } \\
\text { - dla osób rezygnujących z systemu bazowego }\end{array}$ \\
\hline
\end{tabular}

Źródło: PIU, E\&Y (2013: 16); PIU (2011: 8); Więckowska, Osak (2010: 214).

Warto zwrócić uwagę, że istnieją kraje UE (np. Holandia), w których bazowy system zabezpieczenia zdrowotnego funkcjonuje w oparciu o prywatnie finansowane przez świadczeniobiorców ubezpieczenia zdrowotne o charakterze obowiązkowym.

W krajach UE prywatne ubezpieczenia zdrowotne rozwijają się przede wszystkim jako element uzupełniający lub funkcjonujący równolegle do publicznego systemu ochrony zdrowia. Poniższy wykres przedstawia procentowy udział posiadaczy dodatkowych ubezpieczeń zdrowotnych w populacjach wybranych krajów członkowskich i państw będących stroną układów i porozumień z UE. 


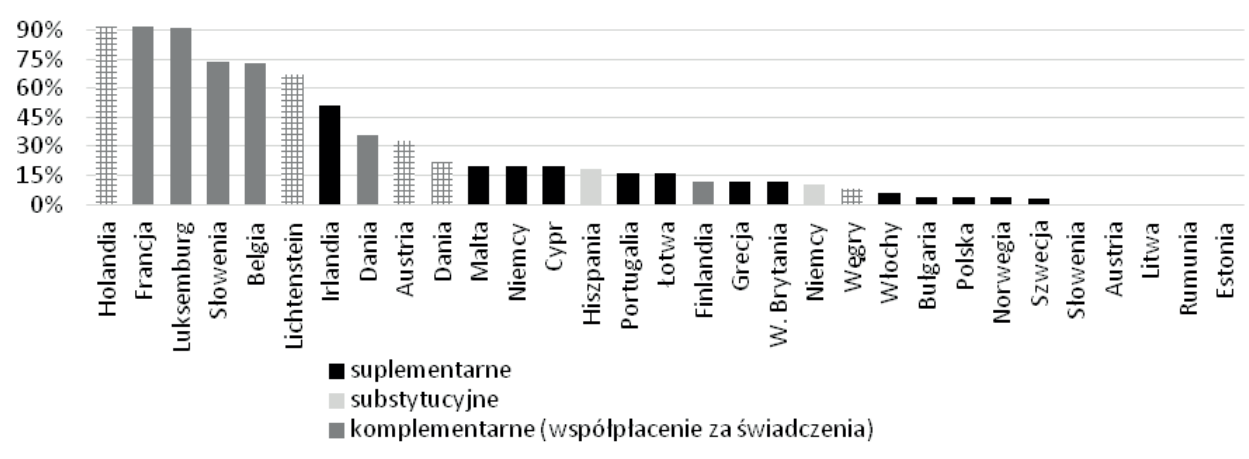

Wykres 9. Odsetek populacji objętej dodatkowymi ubezpieczeniami zdrowotnymi w podziale na typ ochrony - rok 2008

Źródło: Thomson, Mossialos (2009: 28).

Zaprezentowane dane nie uwzględniają zróżnicowania w zakresie ochrony, obrazują jedynie wysycenie rynku. Kraje, w których występują systemy mieszane, zostały przedstawione dwukrotnie.

Niska dostępność świadczeń realizowanych w ramach systemu bazowego to podstawowy czynnik wpływający na rozwój rynku ubezpieczeń suplementarnych. Ograniczony zakres świadczeń gwarantowanych w systemie bazowym lub współpłacenie stymulują rozwój systemów komplementarnych. Jak widać na wykresie 9, największe udziały populacji objętej dodatkowym ubezpieczeniem mają miejsce w tych krajach, gdzie rozwijają się ubezpieczenia komplementarne.

Rynek dodatkowych ubezpieczeń zdrowotnych jest w Polsce wciąż bardzo słabo rozwinięty. W porównaniu z innymi krajami UE Polska ma niekorzystną strukturę prywatnych wydatków na ochronę zdrowia. Obecnie zdecydowana większość świadczeń opieki zdrowotnej pokrywanych ze środków prywatnych jest finansowana na zasadzie opłaty za poszczególne świadczenia. Aktualnie współpłacenie Polaków z własnej kieszeni wynosi ok. 33\% wszystkich wydatków na zdrowie i plasuje Polskę nieco powyżej średniej unijnej (Fal 2013: 48-49).

W opinii przedstawicieli branży ubezpieczeniowej dwa podstawowe czynniki utrudniają rozwój rynku dodatkowych ubezpieczeń zdrowotnych w Polsce. Po pierwsze jest to szeroki zakres zagwarantowanych ustawowo świadczeń finansowanych ze środków publicznych. Drugim czynnikiem jest brak odpowiednich regulacji, sprzyjających tworzeniu prywatnych ubezpieczeń zdrowotnych. Konkurencją dla firm ubezpieczeniowych stały się podmioty oferujące abonamenty medyczne, które działają na podstawie mniej restrykcyjnego niż przepisy prawa ubezpieczeniowego Kodeksu spółek handlowych, dzięki czemu mogą być bardziej konkurencyjne cenowo (Golinowska 2012: 107-108). Działalność prywatnych firm medycznych nie musi być prowadzona w formie spółki akcyjnej lub towarzystwa ubezpieczeń wzajemnych. Podmioty te nie 
muszą spełniać wymogów dotyczących wysokości kapitału zakładowego, nie muszą tworzyć rezerw ani przekazywać sprawozdań finansowych do Komisji Nadzoru Finansowego (KNF), ich oferta produktowa nie musi być przygotowana w oparciu o analizę aktuarialną, a umowy związane ze świadczeniem usług zdrowotnych nie podlegają takim obostrzeniom, jak umowy ubezpieczenia (PIU, E\&Y 2013: 20).

Rozwój dodatkowych ubezpieczeń mógłby stymulować prywatne wydatki na ochronę zdrowia, a tym samym zmniejszać zadłużenie systemu państwowej opieki zdrowotnej. Co więcej upowszechnienie dodatkowych ubezpieczeń zdrowotnych może doprowadzić do:

- korzystniejszej struktury wydatków prywatnych na ochronę zdrowia;

- zwiększenia środków finansowych w ochronie zdrowia z korzyścią dla świadczeniodawców, lekarzy oraz pracodawców;

- częściowego odciążenia systemu bazowego (korzyści dla osób nieposiadających dodatkowych ubezpieczeń zdrowotnych) (Rozkrut 2013: 35-36).

Aby mechanizm dobrowolnych ubezpieczeń zdrowotnych spełnił pokładane w nim nadzieje, oferowane produkty powinny:

- być dostępne powszechnie - muszą wnosić wartość dodaną dla pacjenta i być dla niego dostępne cenowo;

- móc być tak skalkulowane, aby zbierana składka przynajmniej pokryła koszty procedur medycznych - towarzystwa ubezpieczeń powinny chcieć je zaoferować i konkurować o ubezpieczonego;

- stać się realną częścią systemu opieki zdrowotnej - muszą pokrywać i zabezpieczać realną część potrzeb zdrowotnych społeczeństwa (Fal 2013: 50).

Jak wskazują eksperci, rozwój rynku dodatkowych ubezpieczeń zdrowotnych w Polsce będzie na pewno wymagał podjęcia szeregu działań obejmujących m.in.:

- wprowadzenia precyzyjnej definicji dodatkowego ubezpieczenia zdrowotnego;

- umożliwienia oferowania w ramach ubezpieczeń dodatkowych świadczeń z zakresu profilaktyki oraz medycyny pracy;

- określenia szczegółowych warunków współpracy ubezpieczycieli ze świadczeniodawcami posiadającymi kontrakty z NFZ;

- umożliwienia pracodawcom finansowania polis prywatnego ubezpieczenia zdrowotnego ze środków zakładowego funduszu świadczeń socjalnych;

- określenia minimalnych wymagań, jakie powinny spełniać umowy dodatkowych ubezpieczeń zdrowotnych (PIU, E\&Y 2013: 21).

Jak wskazują dotychczasowe doświadczenia, bez podjęcia tych kroków stworzenie rozwiązania efektywnie wspierającego publiczny system ochrony zdrowia nie będzie możliwe. Bez precyzyjnie określonych ram prawnych i działań upowszechniających dodatkowe ubezpieczenia zdrowotne skuteczne odciążenie systemu bazowego nie będzie realizowane. 


\section{PODSUMOWANIE}

Państwowy system ochrony zdrowia w Polsce, pomimo zwiększania wydatków z budżetu państwa, nie działa efektywnie. Obywatele, aby w realnie krótkim czasie uzyskać potrzebną pomoc medyczną, zmuszeni są do współfinansowania leczenia ze środków prywatnych. $Z$ uwagi na fakt, że ok. 90\% środków własnych obywateli, wydatkowanych na zaspokojenie potrzeb związanych z ochroną zdrowia, procedowanych jest w sposób niezinstytucjonalizowany, trudno prowadzić efektywną politykę wspierającą państwowy system ochrony zdrowia. Taka struktura wydatków to efekt przede wszystkim barier legislacyjnych uniemożliwiających skuteczny rozwój dodatkowych ubezpieczeń zdrowotnych. Jak pokazują przykłady wielu krajów europejskich, dodatkowe ubezpieczenia zdrowotne z pozytywnym skutkiem wspierają państwowe systemy ochrony zdrowia. W obliczu ciągle rosnących potrzeb świadczeniobiorców wspieranie powszechności systemu dobrowolnych ubezpieczeń umożliwi wprowadzenie skoordynowanej z systemem państwowym, a zatem bardziej skutecznej, opieki zdrowotnej dla obywateli.

\section{BIBLIOGRAFIA}

Fal D. (2013), Korzyści z rozwoju rynku dodatkowych ubezpieczeń zdrowotnych w Polsce, „Wiadomości Ubezpieczeniowe", nr 4, s. 47-60.

Golinowska S. (red.), (2012), Polska. Zarys systemu ochrony zdrowia, NFZ, Warszawa.

Koziński M. (2014), Narodowy Rachunek Zdrowia za 2012 rok, GUS, Warszawa.

Łanda K. (2013), Dostępność świadczeń gwarantowanych w Polsce na podstawie Barometru Fundacji Watch Health Care, „Wiadomości Ubezpieczeniowe”, nr 4, s. 9-12.

Magda I., Szczygielski K. (2011), Ocena możliwości poprawy działania polskiego systemu ochrony zdrowia. Wspótpłacenie i prywatne ubezpieczenia zdrowotne, E\&Y, Warszawa.

Mossialos E., Thomson S. (2004), Voluntary Health Insurance in the European Union, World Health Organization, Geneva.

OECD (2004), Private Health Insurance in OECD Countries, OECD Publishing, Paris.

OECD (2004), Proposal of a taxonomy health insurance, OECD Study on Private Health Insurance, OECD Health Project, Organisation for Economic Cooperation and Development.

OECD (2013), Health at a Glance 2013: OECD Indicators, OECD Publishing, Paris.

PIU (2011), Rola prywatnych ubezpieczeń zdrowotnych w systemie ochrony zdrowia. Jak wptywaja na dostęp do świadczeń, innowacji i leków - kluczowe tezy i rekomendacje, PIU, Warszawa.

PIU, E\&Y (2013), Rola i funkcja dodatkowych ubezpieczeń zdrowotnych we wspótczesnych systemach ochrony zdrowia - analiza i rekomendacje dla Polski, PIU, Warszawa.

Rozkrut M. (2013), Analiza możliwości zaspokojenia rosnacych potrzeb zdrowotnych. Prognozy rozwoju rynku dodatkowych ubezpieczeń zdrowotnych $w$ Polsce, „Wiadomości Ubezpieczeniowe", nr 4, s. 33-46.

Siwiak K. (red.), (2014), Sytuacja gospodarstw domowych w 2013 r. w świetle wyników badań budżetów gospodarstw domowych, GUS, Warszawa.

Thomson S., Mossialos E. (2009), Private health insurance in the European Union, LSE Health and Social Care London School of Economics and Political Science, London. 
Więckowska E., Osak M. (2010), Potencjat prywatnych ubezpieczeń zdrowotnych jako źródta finansowania opieki zdrowotnej w Polsce, [w:] W. Ronka-Chmielowiec (red.), Ubezpieczenia emerytalne, spoleczne i metody aktuarialne, Wydawnictwo Uniwersytetu Ekonomicznego we Wrocławiu, Wrocław, s. 212-219.

\title{
Matgorzata Jeziorska
}

\section{PRIVATE HEALTH INSURANCES AS AN INSTRUMENT ALLEVIATING THE BURDEN ON PUBLIC HEALTH CARE SYSTEM IN POLAND}

\begin{abstract}
This article focuses on increasing demand for health services within polish national care system. It presents demographic, economic and social development context of this situation. The rules governing polish national care system are also demonstrated. The privet health insurances are indicated as an instrument alleviating the burden on public health care system. The data used come from Central Statistical Office of Poland and Eurostat.

Keywords: national health system, noncompulsory private health insurance, life expectancy, health care expenditure.
\end{abstract}

